\title{
sciendo
}

KAMIL JANECZEK ${ }^{1}$ FAUSTYNA PIĘDEL ${ }^{2}$, KLAUDIA PAGACZ², ANDRZEJ EMERYK ${ }^{1}$

\section{Emigration as a way to a better future? - plans for international migration among students of the Medical University of Lublin}

\begin{abstract}
Introduction. Completing medical studies provides many opportunities. The professional qualifications of doctors are recognized in most hospitals in the European Union and the freedom of movement is conducive to migration abroad. Financial conditions also encourage searching for work in other countries.

Aim. The main purpose of this paper is to present the problem of international migration through the eyes of students of the Medical University of Lublin. We carried out an analysis of the motives and activities which lead students to look for work abroad.

Material and methods. The study was conducted in 2018 using the diagnostic survey method. The $3^{\text {rd }}-6^{\text {th }}$ year students of the medical faculty were given the task to fill out an online questionnaire. As many as $63.2 \%$ of the 87 respondents were women. The questionnaire included 10 questions regarding the demographic situation of the respondents, their willingness and motives to take up work abroad in the future, and also the actions they are taking to reach that goal (e.g. learning foreign languages).

Results. After completing their medical studies, 32 respondents (36.8\%) plan to start working outside of Poland. It was found that men declare a desire to emigrate more often than women $(\mathrm{p}=0.002)$. The motivation of people deciding to stay, turned out to be the proximity of their family home, while emigration was motivated mainly by financial reasons (32 people, $100 \%)$ and more specialization opportunities (28 people, $87.5 \%$ ). Germany was the most frequently mentioned migration destination by the respondents. There was a strong relationship between the foreign language which the respondents were learning and their planned direction of emigration $(\mathrm{p}=0.029, \mathrm{~V}=0.643)$.

Conclusions. Foreign emigration is considered by an increasing number of medical students. Third year students also take into account working abroad. Due to the issue of migration, it is necessary to look for strategic actions that will ensure the proper functioning of healthcare in Poland.
\end{abstract}

Keywords: migration, emigration, student, medicine, specialization.

DOI: $10.2478 /$ pjph-2019-0009

\section{INTRODUCTION}

The typical path of a person who aims to become a doctor in the future consists of six years of medical studies, twelve months of a postgraduate internship, and then from four to six years of residency (training in a selected specialty, for example pediatrics, gynecology). Specialization is not a formally obligatory element of the medical career, but a doctor who does not have a specialization is limited in terms of developing a career.

Completion of medical studies provides many opportunities, one of them is the possibility of working abroad. Many doctors choose to emigrate because their professional qualifications are recognized in other European Union (EU) member states and due to the freedom of movement in the EU. In the Polish Language Dictionary, we can find the following explanation of the word ,migration": the movement of people within a country or between different countries in order to change the permanent place of residence or for a certain period, due to political, ethnic, religious, or economic factors [1]. We distinguish two types of migration among health care workers: permanent migration and transient migration. The causes of permanent migration include: economic reasons (higher standard of living, better living conditions, better financial conditions), greater opportunities for professional development, and unplanned displacements related to e.g. the migration of another member of the family. On the other hand, temporary migrations may result from: temporary work outside of Poland undertaken to improve the financial situation of the family, and the desire to acquire knowledge and develop new skills for further work in the home country [2].

Since Poland's accession to the European Union (2004), the number of young doctors who decide to work abroad has been constantly increasing. Financial conditions offered on the Polish labor market do not satisfy all the needs of young doctors and do not encourage doctors graduating from foreign universities to look for a job in Poland. According to the Polish Supreme Medical Council (NIL), in 2017 there were 134864 doctors in Poland, 8150 of whom work in the Lublin province. According to the data presented in the report of the Organization for Economic Co-operation and Development (OECD),

${ }^{1}$ Department of Paediatric Pulmonology and Rheumatology, II Chair of Paediatrics, Medical University of Lublin, Poland

${ }^{2}$ Students' Scientific Association at the Department of Paediatric Pulmonology and Rheumatology, Medical University of Lublin, Poland 
there were 2.3 doctors for every 1000 inhabitants in Poland, which was the lowest result in the entire European Union. It is believed that this has been caused by the emigration of young doctors to Western countries. On average, every fifth doctor in Poland, in comparison to the number of medical graduates in a given year, asks the Supreme Medical Council to issue a certificate thanks to which their qualifications will be recognized in other European Union countries. In 2017, NIL issued 747 certificates $(8 \%$ more than in 2016) [3].

\section{AIM}

The main purpose of this paper is to present the problem of international migration through the eyes of students of the Medical University of Lublin. An attempt was made to assess the occurrence of emigration plans among medical students in relation to selected variables: gender, education stage (year of study), and foreign language learning.

\section{MATERIAL AND METHODS}

The study was conducted in April 2018 according to the diagnostic survey method [4-7]. A questionnaire was carried out among the 3rd-6th year students of the Medical University in Lublin. It was posted on Facebook and was available only for those students for a period of two weeks.

The questionnaire featured 10 questions regarding the demographic situation of the respondents (gender, age, year of study), their willingness and motives for working abroad in the future, and the actions they were taking to achieve this (e.g. foreign language learning). The respondents were also asked to choose a possible destination of emigration. To take part in the study, students had to download the online questionnaire, fill with their answers, and then save and send the completed form. In the questions about the students' motives for undertaking work abroad in the future and what they were doing to accomplish this, it was possible to write more than one answer.

Participation in the study was voluntary and anonymous. The study included 87 students who correctly completed the survey. The obtained results were put together in MS Excel 2016 and Statistica 12 was used for statistical analysis. To describe the structure of the group of respondents, we used the numbers and percentages of persons characterized by a given feature. In order to verify the hypotheses regarding the existence of a relationship between the studied variables, Pearson's chi-squared test was used. Cramer's V coefficient was used to determine the strength of dependencies between the variables.

\section{RESULTS}

Students of the medical faculty form online groups where they exchange scientific materials and other useful information. The questionnaire was posted on four online groups (third, fourth, fifth, and sixth year students of medicine). Every student who was an active member of a given group had access to the survey (a total of about 800 students). The survey was downloaded by 116 people, 96 people completed and sent it back. 87 of them, who correctly filled out the questionnaires, were included in the analysis (Figure 1).

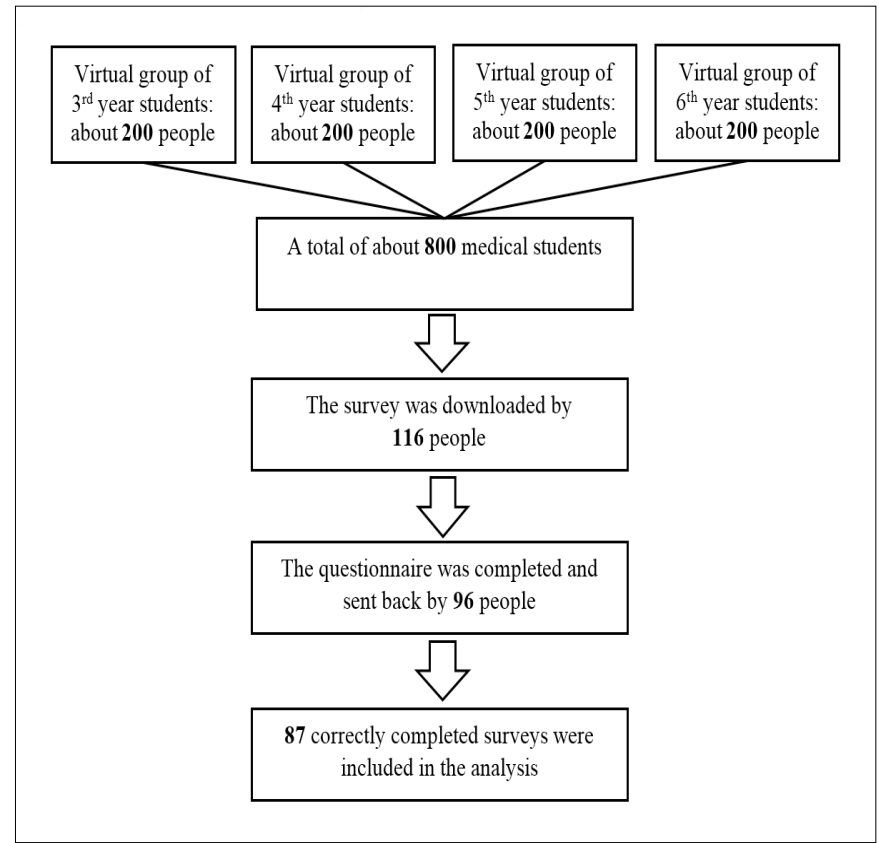

FIGURE 1. The number of online survey questionnaires collected, completed and sent back and included in the analysis.

Of the 87 respondents, $63.2 \%(n=55)$ were women. The average age of respondents was $23 \pm 1.6$ years.

Table 1 shows the number of students declaring their willingness to emigrate after completing their medical studies.

TABLE 1. Students declaring their willingness to emigrate after completing their medical studies.

\begin{tabular}{lccc}
\hline \hline \multirow{2}{*}{ Total $(\mathrm{n}=87)$} & \multicolumn{2}{c}{$\begin{array}{c}\text { Students declaring their } \\
\text { willingness to emigrate }\end{array}$} \\
\cline { 2 - 4 } Gender & & $\mathbf{n}$ & $\mathbf{\%}$ \\
\hline \multirow{2}{*}{ Year of studies } & Women $(\mathrm{n}=55)$ & 32 & 36.8 \\
\cline { 2 - 4 } & Men $(\mathrm{n}=32)$ & 18 & 23.6 \\
\cline { 2 - 4 } & $3(\mathrm{n}=32)$ & 9 & 56.3 \\
\cline { 2 - 4 } & $4(\mathrm{n}=25)$ & 11 & 28.1 \\
\hline & $5(\mathrm{n}=19)$ & 6 & 44.0 \\
\hline & $6(\mathrm{n}=11)$ & 5 & 31.6 \\
\hline
\end{tabular}

After completing their studies, $36.8 \%(n=32)$ of respondents planned to travel abroad. It is worth noting that the percentage of students planning to emigrate differs depending on the stage of their studies - older students were more likely to emigrate after graduating from medical school. However, the chi-squared test did not show any statistically significant relationship between the education stage (the year of studies) and the willingness to move abroad after graduation $(p=0.263)$. The strength of the relationship was evaluated using Cramer's $\mathrm{V}$ coefficient, which showed a weak relationship between the variables $(\mathrm{V}=0.151)$. Thus, the year of studies does not differentiate the respondents in terms of willingness to move abroad.

It was also examined whether there is a relationship between the gender of respondents and the declared willingness to look for a job outside of Poland. A statistically significant relationship was found between these variables $(p=0.002)$. The strength of the relationship between the analysed variables measured using Cramer's V coefficient indicates the existence of a moderate correlation between the sexes of respondents 
and their declared willingness to emigrate $(\mathrm{V}=0.422)$. Based on the results, it can be concluded that men are more likely to look for work abroad in the future compared to women.

Eight students (25.0\%) made one choice, seventeen (53.1\%) indicated two places of possible migration, the others $(21.9 \%)$ marked three countries. The most frequently mentioned country of emigration was Germany, followed by Great Britain and Sweden (Figure 2).

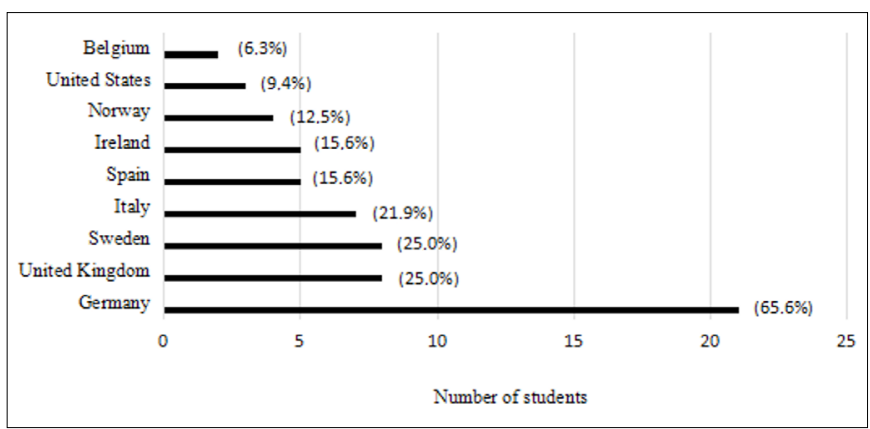

FIGURE 2. The target destination of medical students after graduation (the percentage of persons declaring emigration is given in brackets).

Among the respondents, 44 people (50.6\%) are currently learning at least one foreign language. Twenty-three students $(52.3 \%)$ are learning only one foreign language, 19 students $(43.2 \%)$ are learning two foreign languages, and the last two $(4.5 \%)$ are studying three languages. The most frequently chosen language of future doctors was English (65.9\%), followed by German (45.5\%) (Figure 3).

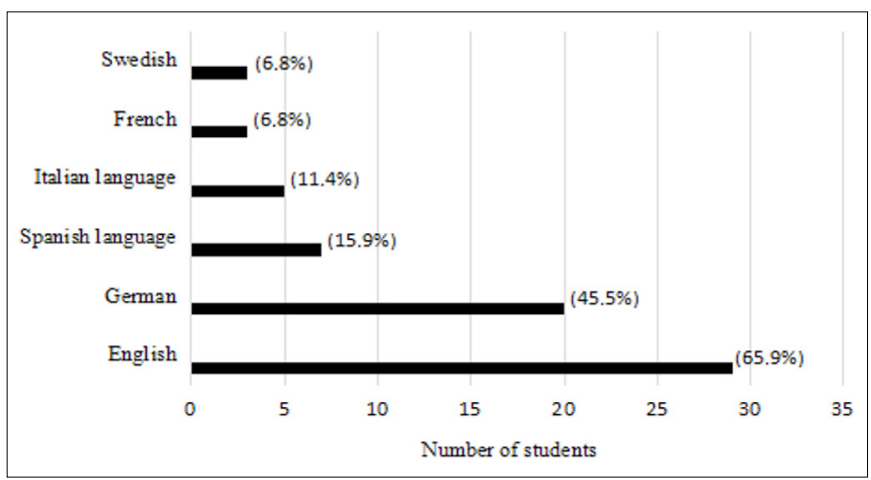

FIGURE 3. The foreign languages which medical students are learning (the percentage of persons who declared learning a foreign language is given in brackets).

There was a statistically significant relationship between the desire to emigrate and studying a foreign language by the respondents $(p=0.00009)$. There were statistically significantly more respondents expressing the willingness of emigration who learn a foreign language in comparison to other respondents.

Table 2 presents the foreign languages learned by students and the migration directions they declare.

The study assessed the correlation between the foreign language studied by the respondents and the direction of migration declared by them. The obtained results show a strong relationship between these variables $(\mathrm{p}=0.029, \mathrm{~V}=0.643)$.
TABLE 2. Foreign languages learned by students and the planned destinations of migration.

\begin{tabular}{lcccccc}
\hline \hline $\begin{array}{c}\text { Direction } \\
\text { of declared } \\
\text { migration }\end{array}$ & English & French & Spanish & German & Swedish & Italian \\
\cline { 2 - 8 } Belgium & 1 & 0 & 0 & 0 & 0 & 0 \\
\hline Spain & 2 & 0 & 3 & 1 & 0 & 1 \\
\hline Ireland & 2 & 1 & 1 & 0 & 1 & 0 \\
\hline Germany & 8 & 0 & 3 & 13 & 0 & 1 \\
\hline Sweden & 5 & 0 & 1 & 0 & 3 & 1 \\
\hline $\begin{array}{l}\text { United } \\
\text { States }\end{array}$ & 0 & 0 & 1 & 0 & 0 & 0 \\
\hline $\begin{array}{l}\text { The United } \\
\text { Kingdom }\end{array}$ & 3 & 0 & 0 & 1 & 1 & 1 \\
\hline Italy & 3 & 0 & 2 & 0 & 0 & 2 \\
\hline
\end{tabular}

The last question in the survey was related to the factors influencing the students' decision to emigrate or to stay in their home country after graduation. People who planned to relocate indicated on average 4 factors affecting their decision to leave the country. The motivation of people deciding to stay, turned out to be family $(89.1 \%$ of students declaring their desire to stay in Poland after completing their studies), and the respondents who wanted to leave their home country were guided mainly by financial considerations (100\% of answers) and the ease of applying for a residency program (87.5\%) (Figure 4).

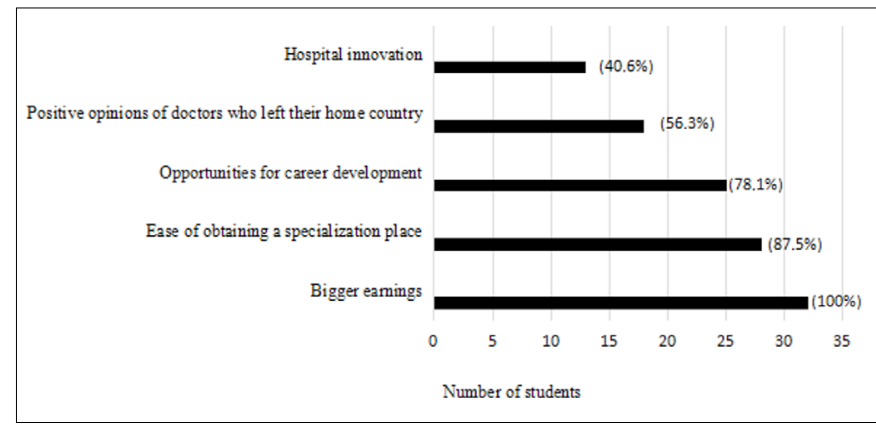

FIGURE 4. Factors influencing the decision to emigrate after graduation (the percentage of people declaring emigration is given in brackets).

\section{DISCUSSION}

The increasing emigration of young doctors from Poland may lead to serious staff shortages in the following decades and in turn, a decrease in the quality of medical services in comparison to European and global standards. There are over six million people employed in the healthcare sector in Poland, which makes it one of the leading EU members in this industry (9.7\% of the European Union's workforce). Despite this fact, the number of healthcare staff per 1000 inhabitants is less than the average in European Union. According to the data established in a report by the Organization for Economic Cooperation and Development (OECD), there were 2.3 physicians per 1000 inhabitants in Poland in 2015, which was the lowest result in the entire European Union where the average was 3.4 doctors per 1000 inhabitants. The largest shortages of medical staff are in the Lubuskie, Opolskie, and Świętokrzyskie provinces.

Piotr Wasilewski and Anna Łuczak discussed the problem of the growing demand for qualified health care workers in our country in the article "The status of medical staff in Poland" published in the bimonthly "Supreme Audit Office". The authors 
found that the level of patients' dissatisfaction is not due to the lack of access to the latest technologies, but to inadequate medical care. Moreover, the basis for staff shortages are the admitted limits for admission to the medical faculty in the 1990s and the growing wave of emigration [8]. Certainly, the insufficient number of medical personnel is also influenced by the increase in the population of the elderly, which, according to estimates of the Central Statistical Office in 2035, will reach $23 \%$ of the general population. Our survey shows that thirty-two students plan to move abroad after graduation and all of them are motivated by financial considerations. The Supreme Audit Office also indicates that young doctors leave Poland to attend residency programs in countries offering more favorable financial conditions.

Another publication on the issue of emigration of young doctors is a review from 2012 by Hanna Jędrkiewicz. The author analyzed the topic of migration and discussions about it in the media, such as the press and the Internet. Hanna Jędrkiewicz found that the topic of the migration of doctors became increasingly widespread in 2006, and the problem itself has often been discussed by the Ministry of Health. Undoubtedly, the increase in the number of specialists leaving our country was at the time connected with Poland's accession to the European Union, which created new opportunities for young scientists to develop and earn money. The data from 2007 analyzed by the author indicates Germany and the United Kingdom as the main directions of emigration [9]. This data is in accordance with the results of our survey, what indicates that certain migration trends have persisted in the medical environment in the last decade. The author sees a threat in the issue of generational replacement among Polish medical staff. She describes this as a "generational collapse in specializations", which emphasizes the importance of the problem and prompts to look for effective solutions. According to her, in the following years there may be a shortage of doctors with experience in Polish hospitals, and of those who will not lack the strength to work on shifts. Confronting the results of our survey with the author's conclusions, we also found that the main motives of students and young doctors for emigrating are unsatisfactory salaries and limited access to specialization places. "Healthcare workers can earn more overseas and do not have to work 80 hours a week like in Poland" - says Dr. Władysław Koś, the head of intensive therapy of the city hospital, in the article by Jędrkiewicz.

Our results are also consistent with the reports of Jośko et al. Studies carried out at the Medical University of Silesia show that almost $43 \%$ of students declared their willingness to move abroad after completing their medical studies. The countries selected by the respondents included: Great Britain (33\%), Sweden (11\%), and Germany (10\%). The respondents were mainly motivated by higher wages and better career prospects [10].

Despite the fact that several thousand young Poles graduate from medical universities every year, we are still struggling with an increasing deficit of doctors in some specialties. In recent years, the emphasis of the Ministry of Health on the education of pediatricians and family medicine specialists is evident. According to data from 2006, about $20 \%$ of medical students declared their will to stay in Poland [9]. Our research shows that over $60 \%$ of medical students at the Medical University of Lublin want to work domestically.
Agnieszka Maciąg distinguishes two types of migration - permanent and transient - in the article "Contemporary problems of migration of medical personnel in Poland and in Europe". The first mainly concerns young people. The author notes that graduates of medical schools decide to travel abroad primarily due to the lack of decent remuneration in the health care sector [2]. This corresponds to the most common reason for emigration plans indicated in our survey - higher earnings outside Poland. Moving abroad is also an opportunity for young doctors to develop their professional careers and raise their qualifications. Students of the Medical University in Lublin also wish to move due to the possibility of professional development and learning about new technologies (25 respondents).

Unsatisfactory working conditions are another motive. In an analysis of the results of a pilot survey conducted in the Świętokrzyskie Province among 66 doctors and nurses, the author draws attention to psychosocial factors conditioning the attitudes of medical personnel. According to the survey, unsatisfactory working conditions are the cause of stress, fatigue, and feeling helpless when dealing with patients [2]. Students of the Medical University do not mention this motive, which is most probably associated with their lack of professional experience.

Based on the results of the survey, it can be concluded that more and more medical students are considering emigration. Third year students are considering the possibility of looking for future work outside of Poland. This is caused by many factors. First of all, financial conditions offered on the Polish market do not meet the needs of young Polish doctors and do not encourage doctors graduating from foreign universities to look for a job in Poland. When examining the influence of various factors on the decision of young physicians, the possibilities offered by western countries seem to be the obvious motivation. However, more than half of the respondents declared that they want to stay in Poland. The majority of people declaring to leave their country after graduation were men (56.3\%). The conclusion is that plans for the future of young doctors depend on their gender. One of the factors influencing this outcome may be that women prefer to start a family in their native country. Such facts can be used by the government to encourage young people to stay and work in Poland. In today's labor market, it is important to improve the social and family conditions of aspiring doctors, for example by providing additional financial support for young parents to allow them to develop a career during parenthood. According to L. Kudlicki, young doctors usually emigrate in the career blossom (aged 36-49), often without a specialization [11]. Marcin Kautsch points out that the main reason for the emigration of young doctors are low earnings. As the best proof of this, he indicates a slowdown in migration at the time when earnings started to grow rapidly, around 2007. According to the analyzed data by Kautsch, other factors which could become a source of motivation to stay in Poland did not change at that time [12]. Also, there is a higher number of 6th year students planning to emigrate than their younger colleagues. The reason seems to be obvious - after 3 years of mostly theoretical lessons, young doctors have a chance to work in hospitals for the first time. They are familiarized with the structure of hospitals and working conditions in Poland. Moreover, they obtain opinions from more experienced doctors. These aspects tend to raise doubts among students and make them question 
their decisions. Therefore, it would be recommended for them to begin practical classes in hospitals from the very beginning of their medical studies.

\section{CONCLUSIONS}

Currently, more and more medical students are considering moving abroad. The subject of migration is still relevant and it is necessary to look for strategic actions which will ensure the proper functioning of healthcare in Poland.

\section{REFERENCES}

1. Dunaj B. Słownik współczesnego języka polskiego. Warszawa: Wydawnictwo Wilga; 1996. p. 521.

2. Maciąg A. Współczesne problemy migracji personelu medycznego w Polsce i Europie. Ekonomia i Prawo. 2012;2:99.

3. http://www.rp.pl/Lekarze-i-pielegniarki/303269942-Lekarze-spoza-UEnie-beda-musieli-nostryfikowac-dyplomu.html (assessed: 24.06.2018).

4. Krajewski M. O metodologii nauk i zasadach pisarstwa naukowego. Uwagi podstawowe. Gliwice: Uniwersytet Śląski; 2010.

5. Andrews FM. Construct validity and error components of survey measures: A structural modeling approach. Public Opinion Quarterly. 1984;48:40922.

6. Cook C, Heath F, Thompson RL. A meta-analysis of response rates in webor Internet-based surveys. Educ Psychol Meas. 2000;60:821-36.

7. Dillman DA. Mail and internet surveys: The tailored design method ( $2^{\text {nd }}$ ed.). New York: Wiley; 2007.

8. Wasilewski P, Łuczak J. Stan kadry medycznej w Polsce. Kontr Państw. 2016;5:63-77.

9. Jędrkiewicz H. Problematyka migracji lekarzy specjalistów w wybranych czasopismach i na internetowych forach medyków. Probl Hig Epidemiol. 2012;93(1):216-22.

10. Jośko J, Kostkiewicz M, Mazurek M, et al. Ojczyzna czy obczyzna? plany zawodowe studentów Śląskiej Akademii Medycznej. Probl Hig Epidemiol. 2007;88:20-3.

11. Kudlicki L. Nowa Wielka Emigracja. Bezpieczeństwo Narodowe. 2006;1:90-110.

12. Kautsch M. Migracje personelu medycznego i ich skutki dla funkcjonowania systemu ochrony zdrowia w Polsce. Zdrowie Publiczne i Zarządzanie. 2013;11(2):169-79.

Corresponding author

Dr Kamil Janeczek

6 Profesora Antoniego Gębali St., 20-093 Lublin

tel: 817185477

E-mail: kamil.janeczek@umlub.pl 